\title{
21. MAGNETOSTRATIGRAPHY OF SEDIMENTS RECOVERED AT SITES 650, 651, 652, AND 654 (LEG 107, TYRRHENIAN SEA) ${ }^{1}$
}

\author{
J.E.T. Channell, ${ }^{2}$ M. Torii, ${ }^{3}$ and T. Hawthorne ${ }^{2}$
}

\begin{abstract}
Apart from Site 650, core disturbance due to rotary drilling severely compromised the quality of the magnetostratigraphic data obtained from Leg 107 sediments. The correlation of polarity zones to the geomagnetic polarity time scale cannot be made solely on the basis of pattern fit. The proposed correlations are consistent between sites, and this consistency is constrained by the biostratigraphic datums. The resulting biomagnetostratigraphic correlations are reviewed in the synthesis section of this volume. The purpose of this paper is to document the magnetic stratigraphies, and present the preferred correlation to the geomagnetic reversal time scale. Four implications of the proposed correlations are: (1) The Mio-Pliocene boundary occurs in the lowest reversed interval of the Gilbert (Chron 3r) at about 4.9 Ma. (2) The thick pre-Pliocene lacustrine sequence recovered at Site 652 appears to have been deposited entirely within a single reversed polarity chron (Chron 3r). (3) The balatino-type gypsum recovered at Site 654 was also deposited entirely within this polarity chron (Chron 3r). (4) The Tortonian-Messinian boundary occurs within a normal polarity zone which is probably correlative to Chron 6 (Chron 3B) giving a boundary age of about 6.4 Ma.
\end{abstract}

\section{INTRODUCTION}

Many of the Neogene stratotype sections are located in the Mediterranean region. As a result of the unique environment in the Mediterranean during the Neogene, the stratotypes are not well correlated to the open ocean biostratigraphies. Hence, open ocean Neogene biozonations can only be loosely correlated to the stage boundaries (see Berggren et al., 1985; Iaccarino and Papani, 1979; Colalongo et al. 1979; Rio et al., 1984). The correlation of Neogene biostratigraphic events to the geomagnetic reversal time scale, both in the Mediterranean and open ocean, is the only unambiguous method for making the desired correlations. Although the correlation of the geomagnetic reversal time scale to the open ocean biostratigraphies is partly established, there is a severe paucity of magnetostratigraphic data from the Mediterranean Neogene. This is largely due to the fact that most efforts to establish magnetostratigraphies in Mediterranean land sections have been unsuccessful.

Leg 107 provided an opportunity to acquire sorely needed magnetostratigraphies from the Mediterranean Neogene. The stratigraphic objectives of Leg 107 were focused on Site 653 and this was the only site destined for double APC coring. Unfortunately, this was also the site for which the magnetic properties were such that a magnetic stratigraphy could not be resolved (see subsequent paper in this volume for a review of the magnetic properties of Leg 107 sediments). Site 650 was drilled using the APC/XCB technique; the recovery and the lack of core disturbance is such that a well-defined magnetostratigraphy could be resolved, however, the sedimentary sequence at this site does not extend below the uppermost Pliocene. Sites 651, 652, and 654 were drilled using the rotary coring technique. The poor quality magnetostratigraphies from these sites, reported in this paper, are not due to the magnetic properties of the sediments but rather to poor recovery and core disturbance due to the drilling technique used.

\footnotetext{
${ }^{1}$ Kastens, K. A., Mascle, J., et al., 1990. Sci, Results, Proc. ODP, 107: College Station, TX (Ocean Drilling Program).

2 Department of Geology, University of Florida, Gainesville, FL 32611. pan.

3 Departnment of Geology and Mineralogy, Kyoto University. Kyoto 606, Ja-
}

This paper documents the magnetic polarity stratigraphies from Sites $650,651,652$, and 654 , and should be considered together with two other papers in this volume. The first of these papers discusses the magnetic properties of the sediments, and the second discusses the correlation of polarity zones to biostratigraphic datums. The latter provides constraints on the correlation of polarity zones to the geomagnetic reversal time scale.

\section{METHODS}

The shipboard cryogenic magnetometer has the capability to measure magnetic remanence in whole cores or archive halves of core sections. The magnetometer system incorporates an on-line alternating field demagnetizer which can be used to subject the core to peak alternating fields, up to a maximum of $8 \mathrm{mT}$. The cryogenic magnetometer system could not be used to resolve the magnetic stratigraphies from Leg 107 for several reasons. The magnetometer electronics were being modified during the previous leg and failed to reach the ship until midway through the cruise. Hence the system was not used at the first three sites. At Sites 653 and 654 (as well as 652), the peak allowable alternating field $(8 \mathrm{mT})$ was insufficient to resolve a well-defined magnetization component. In addition, the poor physical quality of the core at Sites 652 and 654 necessitated selective subsampling to avoid disturbed intervals. The magnetostratigraphies from Leg 107 are based entirely on subsamples taken by inserting $7-\mathrm{cm}^{3}$ plastic cubes into the sediment. The more indurated Miocene sediments were sampled by sawing oriented cubes from the working splits of the cores.

For all sites discussed in this paper, shipboard progressive alternating field demagnetization up to low peak fields (usually $<20 \mathrm{mT}$ ) was followed by stepwise thermal demagnetization on shore. As discussed in a subsequent paper in this volume, thermal demagnetization is generally more effective at isolating the characteristic magnetization component. The thermal technique involved removing the samples from their plastic containers, wrapping the samples in aluminum foil, and progressively demagnetizing the samples by heating in $50^{\circ} \mathrm{C}$ steps until the magnetization intensities fell below magnetometer noise level. The characteristic high blocking temperature magnetization components were chosen by eye from the orthogonal projections, and their directions computed using principal component analysis (Kirschvink, 1980). The magnetostratigraphies are based on the inclination of the characteristic magnetization component.

The identification of polarity chrons cannot be made solely on the basis of polarity zone pattern-fit to the geomagnetic reversal time scale, due to the poor quality of the records. The proposed correlations are consistent between sites, and this consistency is constrained by the biostratigraphic events. The correlation of biostratigraphic datums to the 
polarity records at Leg 107 sites is the subject of a synthesis paper in this volume.

The polarity chron nomenclature used in this paper follows the traditional nomenclature used by Berggren et al. (1985), with the nomenclature of Cox (1982) given in brackets.

\section{SITE 650}

The samples from Site 650 were progressively thermally demagnetized and the magnetic stratigraphy (Fig. 1, Table 1) was based on the inclination obtained from the high blocking tem- perature component. The magnetic properties of the sediments at this site (see subsequent paper in this volume) were comparatively simple although the reddening of the sediment at the base of the section, immediately above the basalts, appears to have remagnetized the basal $10 \mathrm{~m}$ of the sedimentary section. The base of the Brunhes Epoch, the Jaramillo, and the top of the Olduvai are defined. The total sediment thickness at this site is about $600 \mathrm{~m}$ and the Brunhes is about $415 \mathrm{~m}$ thick. This represents an exceptional thickness of Brunhes-aged sediment with an average sedimentation rate of $568 \mathrm{~m} / \mathrm{m}$.y. The sedimentation

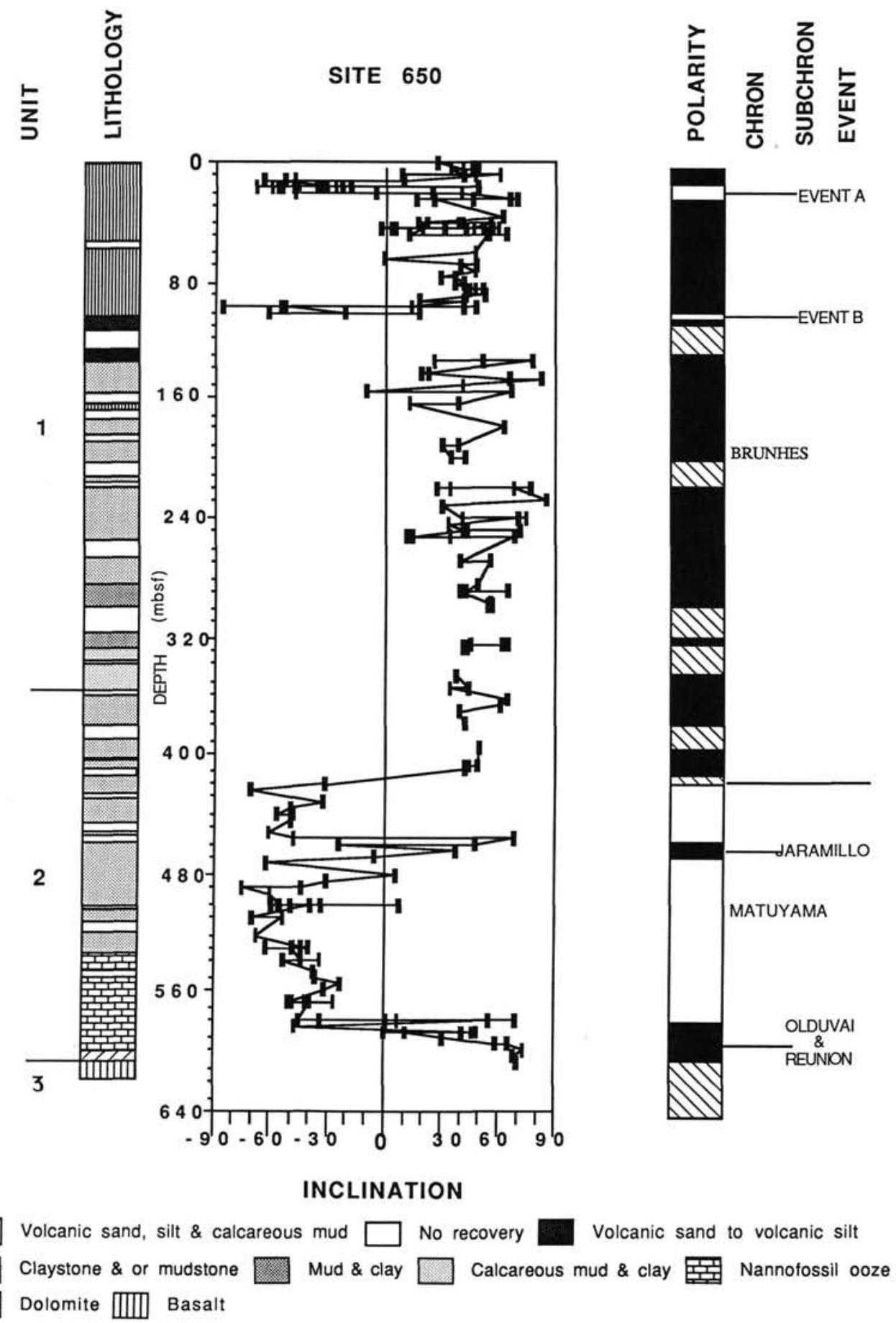

Figure 1. Lithologic log, inclination of the characteristic magnetization component and polarity interpretation for Site 650 . 
Table 1. Locations of samples which bound reversals at Site $\mathbf{6 5 0}$.

\begin{tabular}{lcccc}
\hline & Core & Section & $\begin{array}{c}\text { Interval } \\
\text { (cm) }\end{array}$ & $\begin{array}{c}\text { Depth } \\
\text { (mbsf) }\end{array}$ \\
\hline Top of Event A & 2 & 5 & $138-140$ & 10.39 \\
& 2 & 7 & $12-14$ & 12.31 \\
Base of Event A & 3 & 5 & $96-98$ & 19.67 \\
& 3 & 6 & $29-31$ & 20.5 \\
Top of Event B & 11 & 5 & $100-102$ & 97.71 \\
& 11 & 6 & $85-87$ & 99.06 \\
Base of Event B & 11 & 7 & $48-50$ & 100.16 \\
& 11 & 7 & $24-26$ & 100.45 \\
Top of Matuyama & 45 & 2 & $105-107$ & 408.66 \\
& 47 & 1 & $38-40$ & 421.89 \\
Top of Jaramillo & 50 & 4 & $48-50$ & 455.39 \\
& 50 & 5 & $88-90$ & 457.29 \\
Base of Jaramillo & 51 & 3 & $31-33$ & 463.42 \\
& 52 & 1 & $80-82$ & 470.51 \\
Top of Olduvai & 63 & 3 & $34-36$ & 579.15 \\
& 63 & 3 & $141-143$ & 580.22 \\
\hline
\end{tabular}

rate appears to have been considerably higher in the Brunhes than in the Matuyama (Fig. 2). Two "events" are apparent within the Brunhes (Fig. 1). The details of the magnetic properties of samples recording these "events" and possible age assignments, are discussed elsewhere in this volume (Channell and Torii, this volume). The thermal demagnetization of these samples yielded well-defined high blocking temperature components. We consider that these "events" record geomagnetic field changes within the Brunhes Epoch.

\section{SITE 651}

Site 651 was drilled by rotary coring. The poor recovery and core disturbance severely limited the sampling density. Shipboard alternating field treatment was followed by thermal demagnetization on shore. The magnetostratigraphy (Fig. 3, Table 2 ) is based on the inclination of the high blocking temperature component. Component directions with maximum angular deviation (MAD) values greater than $20^{\circ}$ (Fig. 4) were rejected from further consideration. The total sediment thickness at Site 651 is close to $400 \mathrm{~m}$. The Brunhes is about $320 \mathrm{~m}$ thick at this site but the sample coverage is particularly poor in this interval. The main features of the Matuyama are defined, although the Jaramillo is defined by a single sample (Fig. 3). The basal $50 \mathrm{~m}$ of sediment at this site are hydrothermally dolomitized and reddened. This process has remagnetized the sediments and the high blocking temperature component directions in this part of the core are considered to be secondary. The top of the Olduvai is slightly above this remagnetized interval and lies close to the Plio-Pleistocene boundary. A plot of depth against age of reversals (Fig. 5) indicates an increased sedimentation rate in the Brunhes relative to that in the Matuyama.

\section{SITE 652}

Site 652 was rotary drilled to a depth of 720 mbsf. Marine Plio-Pleistocene sediments (Unit 1) overlie lacustrine (Messinian) sediments of Units 2 and 3 (Fig. 6). As with the other rotary drilled sites, the principal cause of the poorly defined magnetostratigraphy is core disturbance rather than adverse magnetic properties of the sediments. At Site 652 , shipboard alternating field demagnetization was followed by thermal demagnetization on shore. The magnetic stratigraphy presented here is based on stepwise thermal demagnetization. For most samples, the component direction was calculated using principal component analysis of complete thermal demagnetization sequences. However, some samples were only demagnetized up to $300^{\circ} \mathrm{C}$. The main feature of the magnetic stratigraphy at this site is a mixed polar-

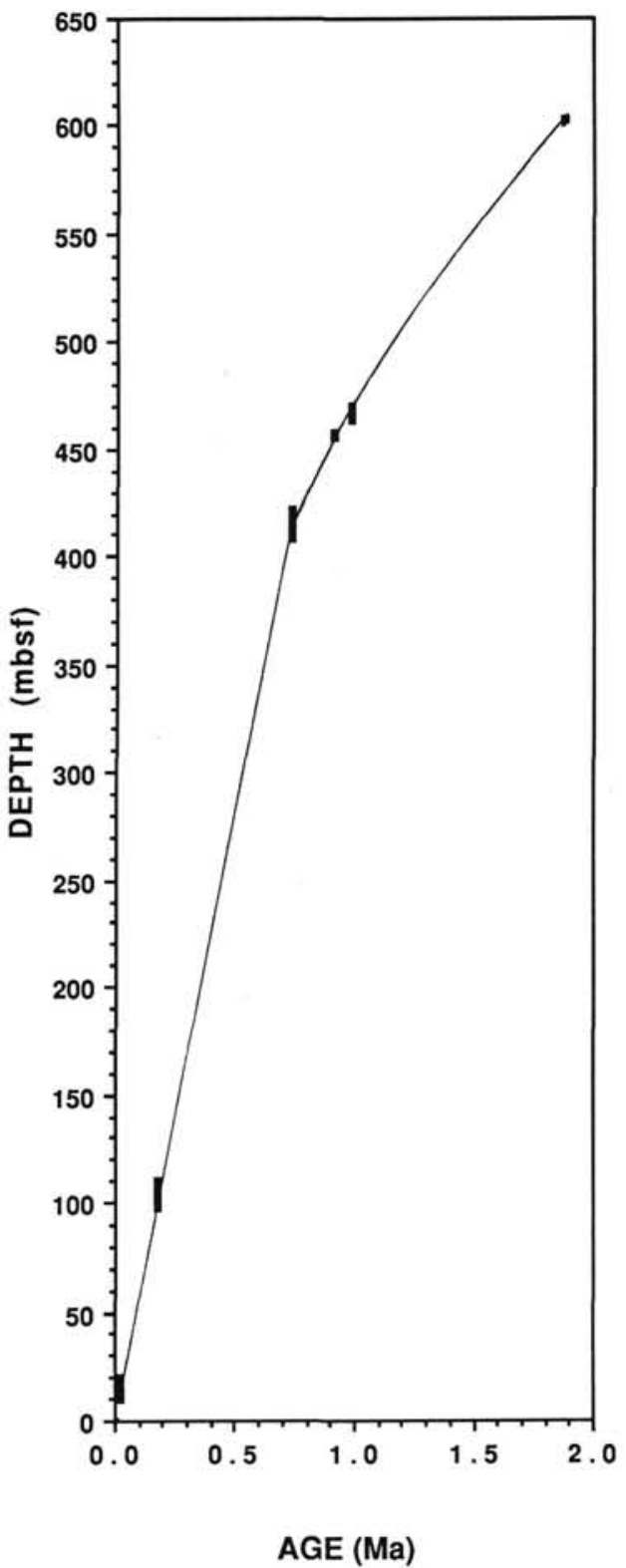

Figure 2. Depth/age plot for Site 650 using the Berggren et al. (1985) time scale to assign ages to polarity reversals.

ity interval overlain by a thick sequence of predominantly reversed polarity (Fig. 6).

The lacustrine sediments of Units 2 and 3 are almost entirely of reversed polarity. Short intervals characterised by positive inclination within this sequence are correlated with intervals of high organic carbon content (see Kastens, Mascle, et al., 1987, p. 439), suggesting that highly reducing conditions in these intervals account for the remagnetization of the sediments. We consider that the entire lacustrine sequence represented by Units 2 and 3 was deposited in a reversed polarity interval corresponding to the lowest reversed interval of the Gilbert (Chron 3r). This requires a minimum sedimentation rate of $871 \mathrm{~m} / \mathrm{m}$.y. for the lacustrine sequence.

The quality of the magnetostratigraphy from Unit 1 is such that the correlation of polarity chrons to the geomagnetic polarity time scale must be considered tentative (Fig. 7, Table 3). A depth vs. age (of reversals) plot for this site yields a curve indi- 


\section{Lithologic Lithology}

Unit

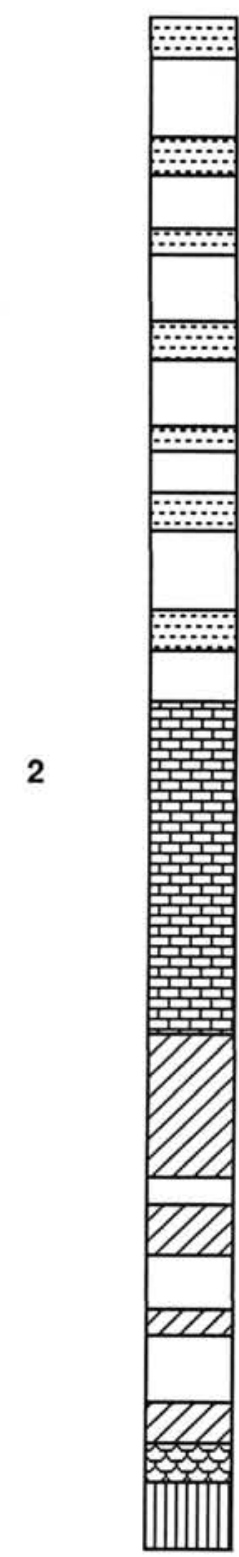

Site 651

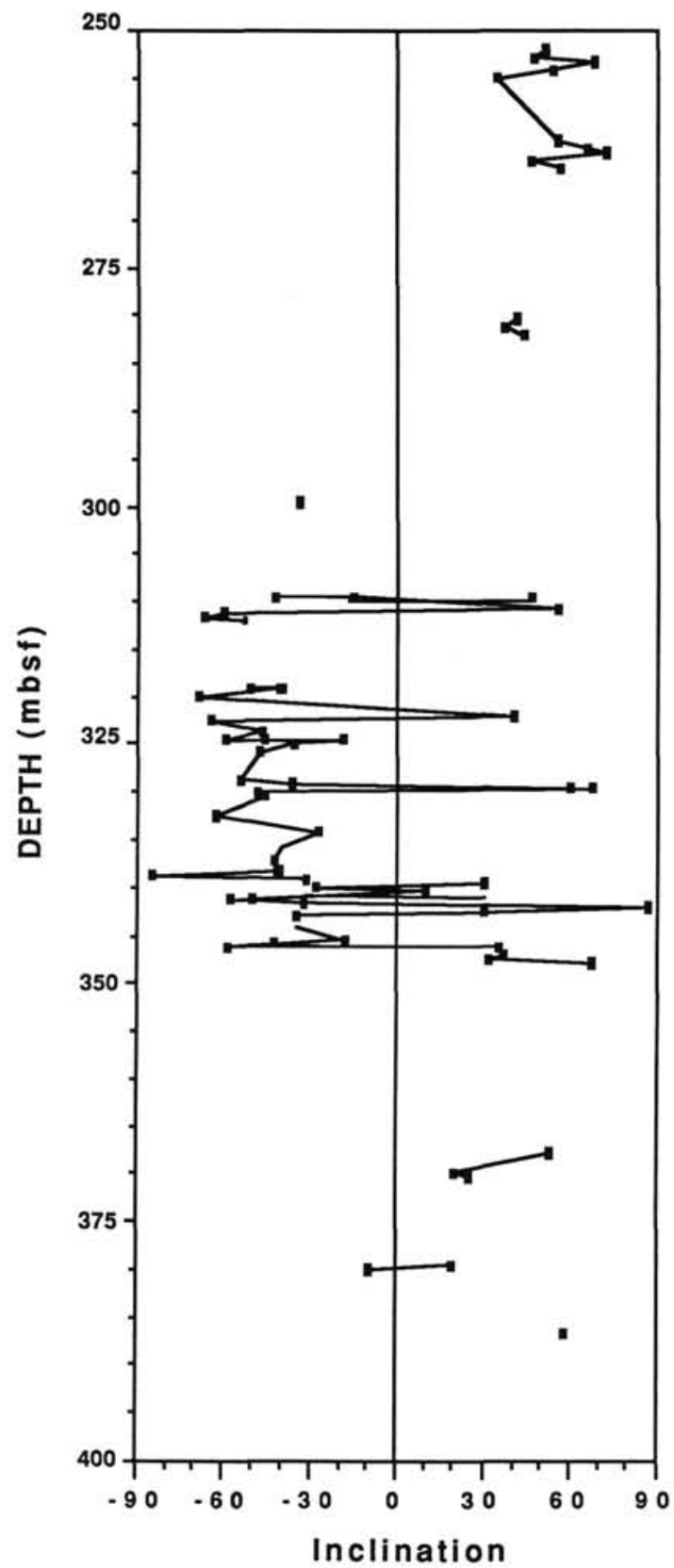

Polarity

Chron

Subchron

Brunhes
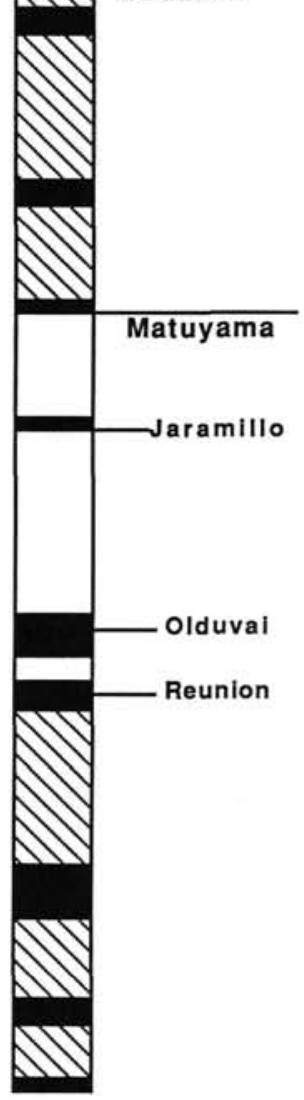

No recovery

Nannofossil ooze

Dolomite

Basalt

Figure 3. Lithologic log, inclination of the characteristic magnetization component, and polarity interpretation for part of the record from Site 651 .

cating gradual changes in sedimentation rate (Fig. 8). If we interpret the reversal close to the base of Unit 1 as the base of the Thvera (Chron 3.3), then the Miocene-Pliocene boundary (at $188 \mathrm{mbsf}$ ) lies within the lowest reversed interval of the Gilbert (Chron 3r) at about 4.9 Ma (Fig. 8).

\section{SITE 654}

Site 654 was rotary drilled. The resulting poor recovery and drilling disturbance gives a fragmentary inclination record (Fig.
9). This record is based on component directions computed by principal component analysis from stepwise thermal demagnetization data, except for the gypsum of Unit 2 which was demagnetized using alternating fields. The maximum angular deviation (MAD) values are generally below $15^{\circ}$ (Fig. 10), and samples with values above $25^{\circ}$ were eliminated from further consideration. Due to the lack of continuity of the record, the interpretations given in Figure 9 and Table 4 should be considered tentative. However the main features of the lower part of the Gauss and of 
Table 2. Locations of samples which bound reversals at Site 651 .

\begin{tabular}{lcccc}
\hline & Core & Section & $\begin{array}{c}\text { Interval } \\
(\mathrm{cm})\end{array}$ & $\begin{array}{c}\text { Depth } \\
\text { (mbsf) }\end{array}$ \\
\hline Base of Brunhes & 34 & 1 & $6-8$ & 309.37 \\
& 34 & 1 & $17-19$ & 309.48 \\
Top of Jaramillo & 35 & 1 & $66-68$ & 319.57 \\
& 35 & 1 & $130-132$ & 320.21 \\
Base of Jaramillo & 35 & 1 & $130-132$ & 320.21 \\
& 35 & 2 & $148-150$ & 321.89 \\
Top of Olduvai & 37 & 3 & $34-36$ & 341.55 \\
& 37 & 3 & $72-79$ & 341.93 \\
Base of Olduvai & 37 & 4 & $146-148$ & 344.16 \\
& 37 & 5 & $108-110$ & 345.29 \\
Top of Reunion & 37 & 6 & $52-54$ & 346.23 \\
& 37 & 6 & $134-136$ & 347.05 \\
\hline
\end{tabular}

the Gilbert appear to be defined. Lack of recovery at the top of Unit 2 means that the record across the Mio-Pliocene boundary is not continuous. The balatino-type gypsum and intercalated marls of Unit 2 give characteristic magnetization components which have negative inclination. We interpret this to indicate that the gypsum and marls of Unit 2 were deposited during the lowest reversed interval of the Gilbert (Chron $3 r$ ). The few recoverable samples from Unit 3 indicate reversed polarity. At the top of Unit 4 , the sediments are reversely magnetized and a polarity sequence is recognized in Unit 4 which may correlate to Chrons 6 and 7 (Chrons 3B and 4).

The plot of depth vs. age (of reversal) for Site 654 , based on the interpretation shown in Figure 9, indicates an approximately constant sedimentation rate for Unit 1 during the Gauss and Gilbert (Fig. 11). Extrapolation of this line through the Gilbert to the Mio-Pliocene boundary implies an age of $4.8 \mathrm{Ma}$ for this boundary. This age is similar to that estimated at Site 652 . For Unit 4, the age/depth plot is close to a straight line if we interpret the polarity sequence in this unit as corresponding to Chrons 6 and 7 (Chrons 3B and 4) (Fig. 11A). If however we interpret this sequence as Chron 5 and 6 (Chrons $3 \mathrm{~A}$ and $3 \mathrm{~B}$ ), the curved age/depth plot infers a very rapid change in sedimentation rate (Fig. 11B). Although there is no certain way to distinguish between these two interpretations, in view of the lack of lithological evidence for changes in sedimentation rate, we favor the correlation to Chrons 6 and 7 (Chrons 3B and 4). If this correlation is correct, the Tortonian/Messinian boundary (at $369.6 \mathrm{mbsf}$ ) has an age of $6.4 \mathrm{Ma}$ (Fig. 11A). The alternative interpretation (Fig. 11B) yields an age of $5.4 \mathrm{Ma}$ for this boundary.

\section{DISCUSSION}

The magnetostratigraphies acquired from Leg 107 sediments are generally of poor quality due to core disturbance due to rotary drilling. The magnetic properties of the sediments from Sites $650,651,652$, and 654 are such that a single magnetization component could usually be resolved. However, aberrant directions are often observed in the inclination records, and we conclude that core disturbance is the main culprit. As a result, the correlations of polarity zones to the geomagnetic reversal time scale are often tentative. Our preferred correlations are self-consistent and do not imply abrupt changes in sedimentation rate, although sedimentation rates appear to have accelerated during the Brunhes Chron at Sites 650 and 651 .

The Miocene-Pliocene boundary was drilled at Sites 652 and 654. Although the recovery and stratigraphic completeness of the boundary interval is greater at Site 652, extrapolation of the age/depth plots through the Gilbert to the Miocene-Pliocene boundary gives an age of 4.8-4.9 Ma for this boundary at both sites. This age is about 0.5 m.y. younger than that given by Ryan et al. (1974) and Berggren et al. (1985) who place this

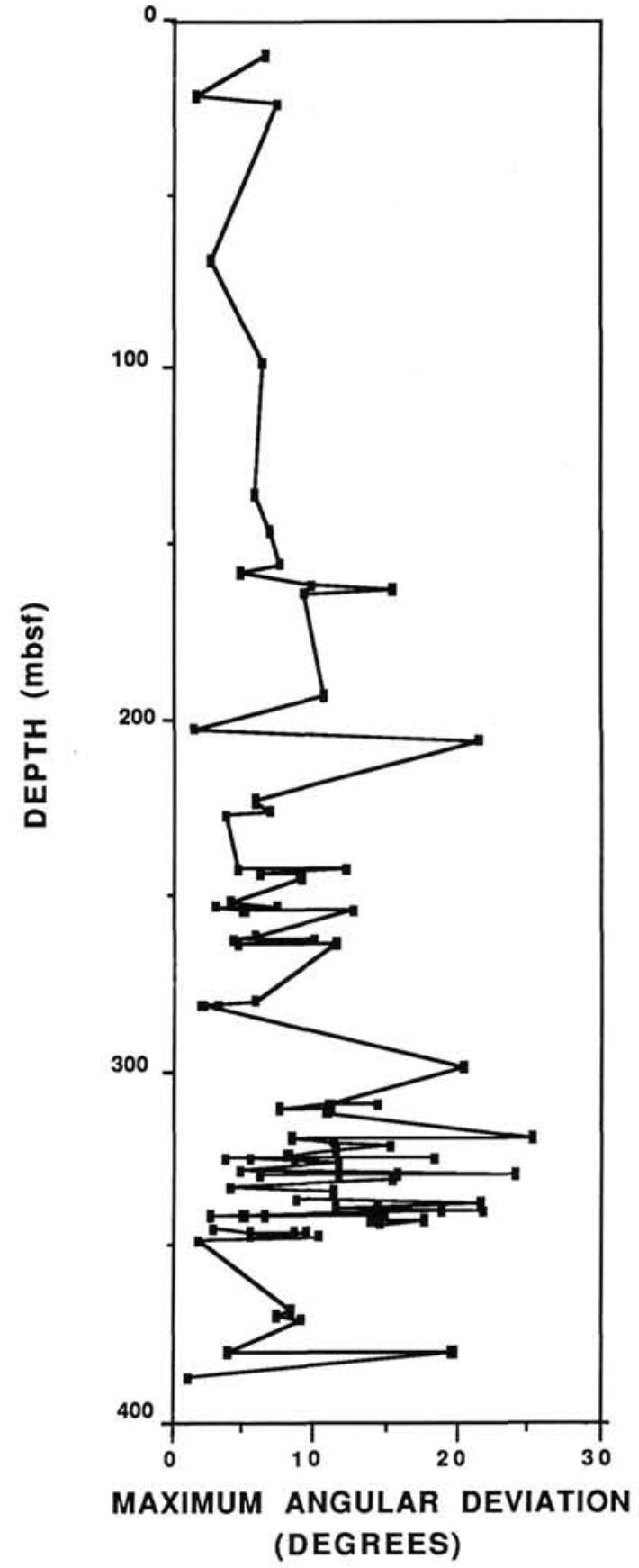

Figure 4. Maximum angular deviation (MAD) values as a function of depth for Site 651 .

boundary at the top of Chron 5 (Chron 3A) at 5.3 Ma. Recent magnetostratigraphic data from land sections in Calabria (Italy) indicate an age for this boundary of $4.8 \mathrm{Ma}$ (Zijderveld et al., $1986)$ or $4.9 \mathrm{Ma}$ (Channell et al., 1988), giving credence to the age obtained here.

The consistent reversed magnetization of the entire lacustrine sequence (Units 2 and 3) at Site 652 implies that it was deposited within the lowest reversed interval of the Gilbert (Chron $3 \mathrm{r}$ ). If this correlation is correct, the minimum sedimentation rate in this sequence was $871 \mathrm{~m} / \mathrm{m}$.y. At Site 654 , the reversed magnetization in the balatino-type gypsum is correlated to the same chron implying that the gypsum (upper evaporite) sequence at Site 654 was also deposited entirely within this time interval. 


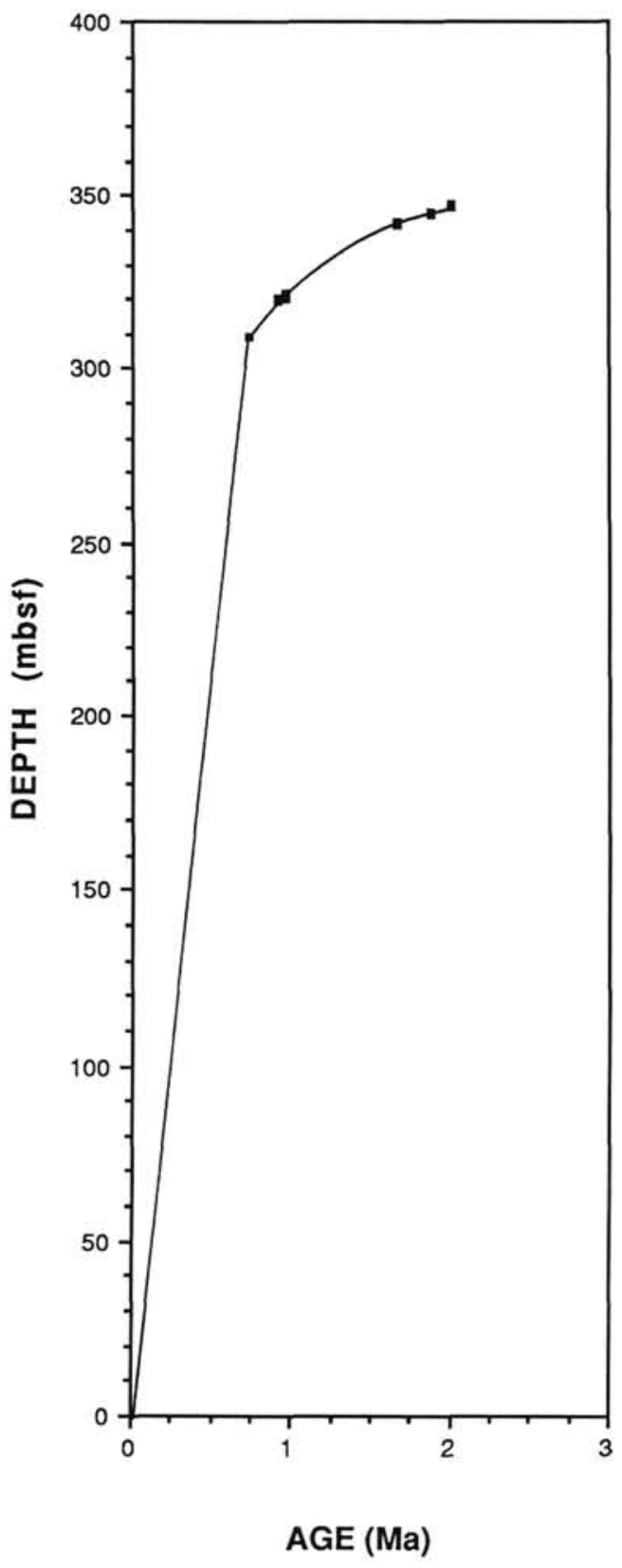

Figure 5. Depth/age plot for Site 651 using the age of reversal boundaries as given by Berggren et al. (1985).

We suppose that the Chron 5 (Chron 3A) at Site 654 is missing in the unconformity at the base of Unit 2 .

The Tortonian-Messinian boundary at Site 654 occurs at 369.9 mbsf within a normal polarity zone. Our preferred correlation of the polarity zones in Unit 4 to the geomagnetic polarity time scale means that the normal interval which contains the boundary is Chron 6 (Chron 3B). If this is the case, the age/depth plots imply an age of $6.4 \mathrm{Ma}$ for the boundary. An alternative correlation which is consistent with the magnetostratigraphy places the boundary in Chron 5 (Chron $3 \mathrm{~A}$ ) at $5.4 \mathrm{Ma}$. The correlation of the Tortonian-Messinian boundary to the geomagnetic polarity time scale is controversial. Langereis et al. (1984) sampled several sections across the Tortonian-Messinian boundary in Crete where the boundary (recognized by the first appearance datum of $G$. conomiozea) occurs in a reversed polarity zone interpreted as the middle part of Chron 5 (Chron 3A-1). Hsü (1986) has reinterpreted this magnetostratigraphy and suggested that the boundary lies in Chron 6r1 (Chron 3Ar), at the same location as in the Blind River section (New Zealand) (Loutit and Kennett, 1979). The problem is exacerbated by the fact that the boundary occurs in a normal polarity zone at Site 654, which we prefer to interpret as Chron 6n (Chron 3B). This is consistent with the work of Moreau et al. (1985) who place the boundary in Chron 6n (Chron 3B) in a section located on the Atlantic coast of Morocco. The problem with these correlations may be associated with the identification and taxonomy of G. conomiozea (see Scott, 1980) rather than with the magnetostratigraphies.

\section{ACKNOWLEDGMENTS}

We acknowledge financial support from the Texas A\&M Research Foundation/USSP.

\section{REFERENCES}

Berggren, W. A., Kent, D. V., and Van Couvering, J. A., 1985. Cenozoic geochronology, In Snelling, N. J. (Ed.) Geochronology and the Geologic Record, Geol. Soc. (London), Spec. Paper, 211-260.

Channell, J.E.T., Rio, D., and Thunell, R. C., 1988. Miocene-Pliocene boundary magnetostratigraphy at Capo Spartivento, Calabria, Italy. Geology, 16:1096-1099.

Colalongo, M. L., Di Grande, A., D’Onofrio, S., Giannelli, L., Iaccarino, S., Massei, R., Romeo, M., and Salvatorini, G., 1979. Stratigraphy of Late Miocene Italian sections straddling the Tortonian/ Messinian boundary. Boll. Soc. Paleontol. It., 18:2.

Cox, A., 1982. Magnetostratigraphic time scale, In Harland, W. B. et al. (Eds.), A Geologic Time Scale: Cambridge (Cambridge Univ. Press), 1-128.

Hsü, K. J., 1986. Unresolved problems concerning the Messinian salinity crisis. G. Geol., 47:203-212.

Iaccarino, S., and Papani, G., 1979. II Messiniano dell'Apennino settentrionale dalla Val d'Arda alla Val Secchia: Stratgraphia e rapporti con il substrato e il Pliocene. Publ. 35 del Progetto IGCP, Universita di Parma.

Kirschvink, J. L., 1980. The least squares line and plane and the analysis of paleomagnetic data. Geophys. J. Roy. Astron. Soc., 62:699718.

Langereis, C. G., Zachariasse, W. J., and Zijderveld, J.D.A., 1984. Late Miocene magnetostratigraphy of Crete. Mar. Micropaleontol., 8: 261-281.

Loutit, T. S., and Kennett, J. P., 1979. Application of carbon isotope stratigraphy to late Miocene shallow marine sediments, New Zealand. Science, 204:1196-1199.

Moreau, M. G., Feinberg, H., and Pozzi, J. P., 1985. Magnetobiostratigraphy of a Late Miocene section from the Moroccan Atlantic margin. Earth Planet Sci. Lett., 76:167-175.

Rio, D., Sprovieri, R., and Raffi, I., 1984. Calcareous plankton biostratigraphy and biochronology of the Pliocene-Lower Pleistocene succession of the Capo Rossello area, Sicily. Mar. Micropaleontol., 9:135-180.

Ryan, W.B.F., Cita, M. B., Rawson, M., Dreyfus, J., Burckle, L. H., and Saito, T., 1974. A paleomagnetic assignment of Neogene stage boundaries and the development of isochronous datum planes between the Mediterranean, the Pacific and Indian Oceans in order to investigate the response of the world ocean to the Mediterranean "salinity crisis." Riv. It. Paleontol., 80:631-688.

Scott, G. H., 1980. Upper Miocene biostratigraphy: does Globorotalia conomiozea occur in the Messinian? Rev. Esp. Micropaleontol., 11: 489-506.

Zijderveld, J.D.A., Zachariasse, J. W., Verhallen, P.J.J.M., and Hilgen, F. J., 1986. The age of the Miocene-Pliocene boundary. Newsl. Stratigr., 16:169-181.

Date of initial receipt: 5 January 1988

Date of acceptance: 20 December 1988

Ms 107B-167 


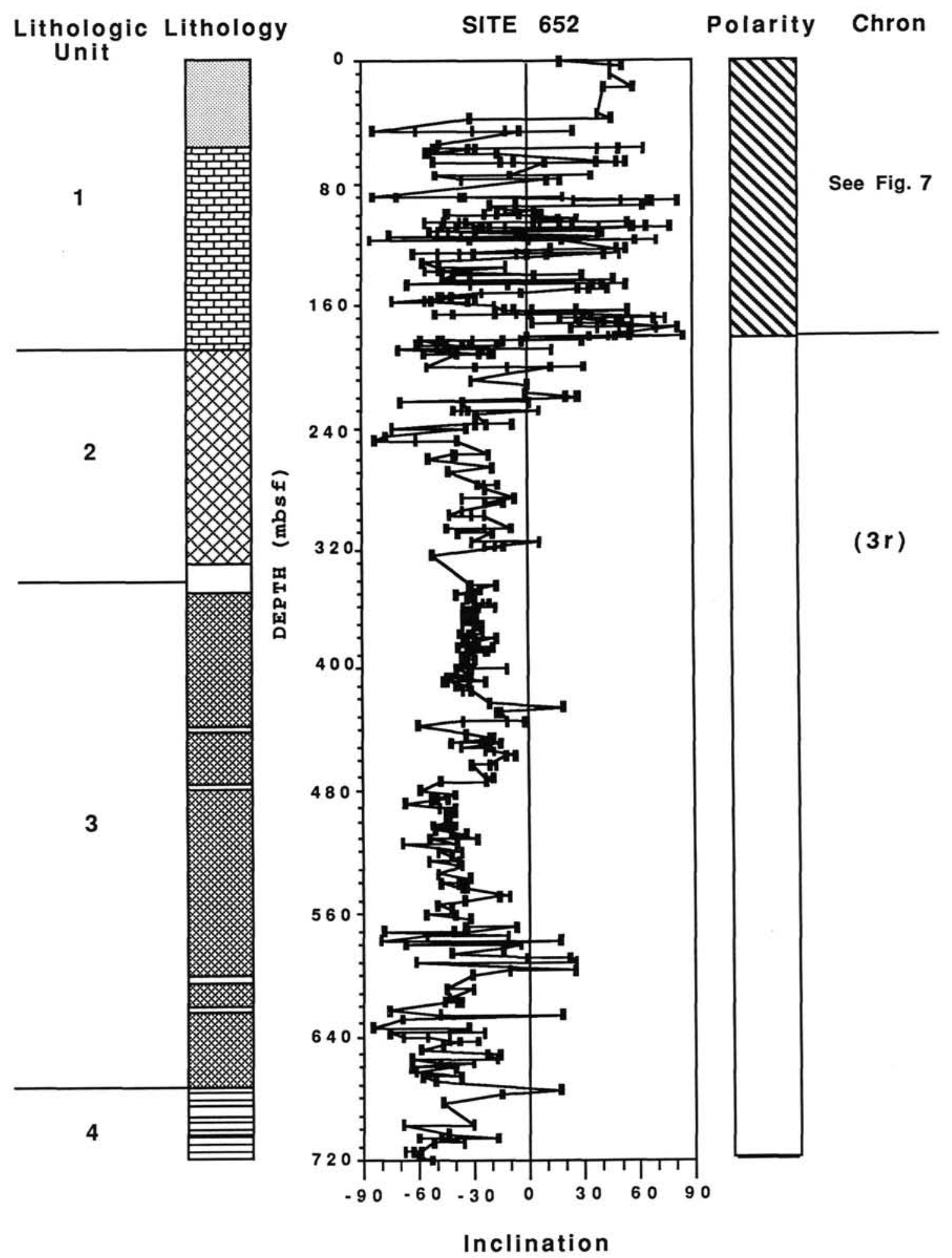

Calcareous mud \& clay ${ }^{5}$ Nannofossil ooze 2

Gypsum \& carbonate bearing turbidites

Gypsum \& carbonate bearing turbidites, sand silts \& clays

Figure 6. Lithologic log and inclination of the characteristic magnetization component for Site 652 . The polarity interpretation for the pre-Pliocene part of the sedimentary sequence is shown. 


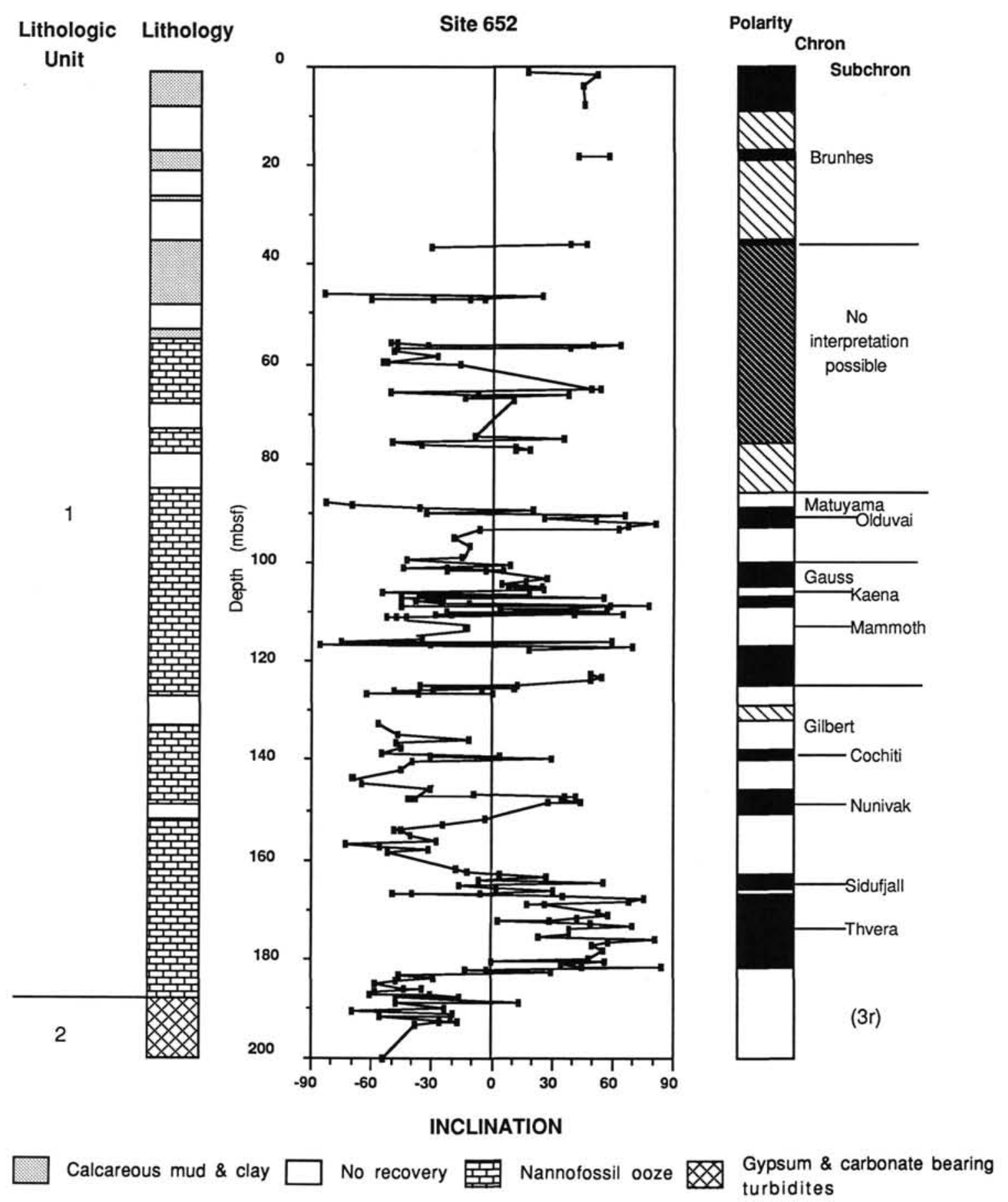

Figure 7. Lithologic log, inclination of the characteristic magnetization component, and polarity interpretation for the upper part of the sedimentary sequence (Unit I) at Site 652 . 
Table 3. Locations of samples which bound reversals at Site 652 .

\begin{tabular}{|c|c|c|c|c|}
\hline & Core & Section & $\begin{array}{l}\text { Interval } \\
(\mathrm{cm})\end{array}$ & $\begin{array}{l}\text { Depth } \\
\text { (mbsf) }\end{array}$ \\
\hline \multirow[t]{2}{*}{ Base of Brunhes } & 4 & 7 & $34-36$ & 36.05 \\
\hline & 5 & 1 & $30-32$ & 36.71 \\
\hline \multirow[t]{2}{*}{ Top of Olduvai } & 10 & 4 & $134-136$ & 90.05 \\
\hline & 10 & 5 & 29-31 & 90.50 \\
\hline \multirow[t]{2}{*}{ Base of Olduvai } & 10 & 7 & $10-12$ & 93.31 \\
\hline & 10 & 7 & $32-24$ & 93.53 \\
\hline \multirow[t]{2}{*}{ Base of Matuyama } & 11 & 6 & $48-50$ & 101.79 \\
\hline & 12 & 1 & $15-17$ & 103.16 \\
\hline \multirow[t]{2}{*}{ Top of Kaena } & 12 & 2 & $120-122$ & 105.71 \\
\hline & 12 & 3 & $20-22$ & 106.21 \\
\hline \multirow[t]{2}{*}{ Base of Kaena } & 12 & 4 & $130-132$ & 108.81 \\
\hline & 12 & 4 & $139-141$ & 108.90 \\
\hline \multirow[t]{2}{*}{ Top of Mammoth } & 12 & 5 & $70-72$ & 109.71 \\
\hline & 12 & 5 & $98-100$ & 109.99 \\
\hline \multirow[t]{2}{*}{ Base of Mammoth } & 13 & 4 & $15-17$ & 116.79 \\
\hline & 13 & 4 & $42-44$ & 117.36 \\
\hline \multirow[t]{2}{*}{ Base of Gauss } & 14 & 2 & $77-79$ & 124.58 \\
\hline & 14 & 2 & $105-107$ & 124.86 \\
\hline \multirow[t]{2}{*}{ Top of Cochiti } & 15 & 5 & $145-147$ & 139.36 \\
\hline & 15 & 6 & 4-6 & 139.45 \\
\hline \multirow[t]{2}{*}{ Base of Cochiti } & 15 & 6 & $81-3$ & 140.22 \\
\hline & 16 & 1 & $64-66$ & 142.15 \\
\hline \multirow[t]{2}{*}{ Top of Nunivak } & 16 & 4 & $75-77$ & 146.76 \\
\hline & 16 & 4 & $142-144$ & 147.43 \\
\hline \multirow[t]{2}{*}{ Base of Nunivak } & 16 & 5 & $124-126$ & 148.75 \\
\hline & 17 & 1 & $71-73$ & 151.92 \\
\hline \multirow[t]{2}{*}{ Top of Sidufjall } & 18 & 2 & $18-20$ & 162.49 \\
\hline & 18 & 2 & $82-84$ & 163.13 \\
\hline \multirow[t]{2}{*}{ Base of Sidufjall } & 18 & 4 & $89-91$ & 166.2 \\
\hline & 18 & 4 & $142-144$ & 166.73 \\
\hline \multirow[t]{2}{*}{ Top of Thvera } & 18 & 5 & $33-35$ & 167.14 \\
\hline & 18 & 5 & $52-54$ & 167.33 \\
\hline \multirow[t]{2}{*}{ Base of Thvera } & 20 & 2 & $11-13$ & 181.82 \\
\hline & 20 & 2 & $108-110$ & 182.79 \\
\hline
\end{tabular}

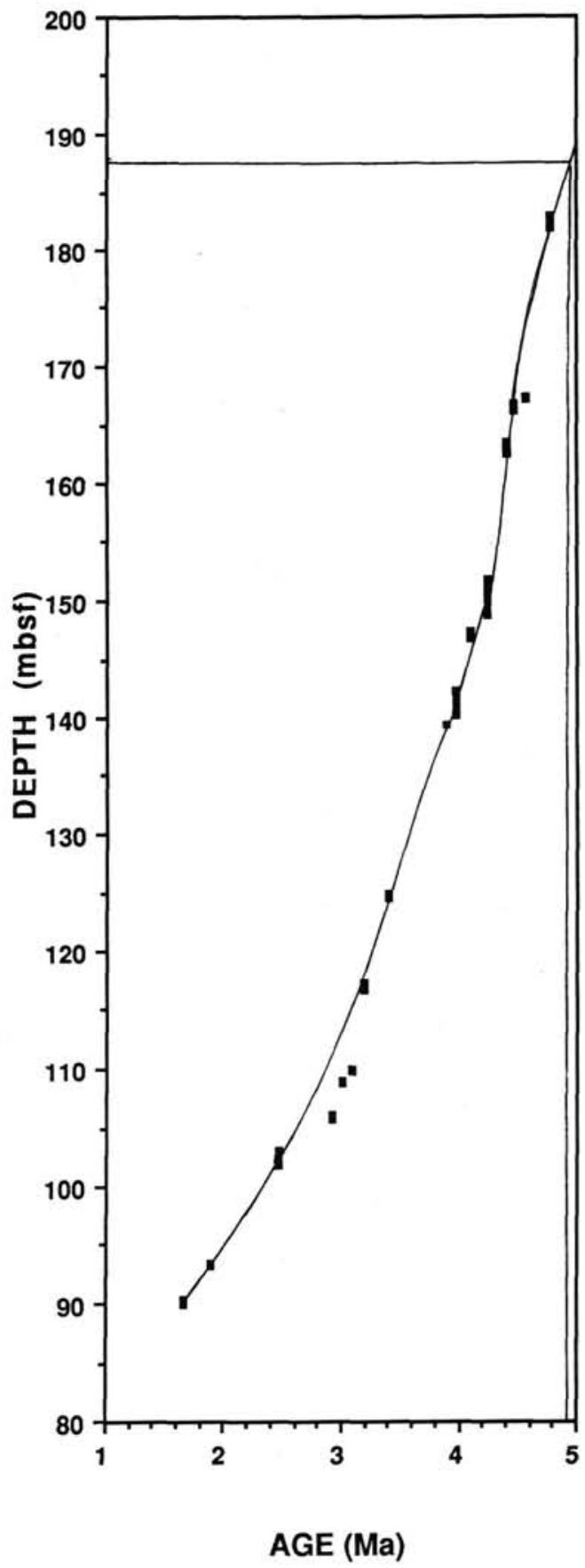

Figure 8. Depth/age plot for Site 652 using the ages of reversal boundaries as given by Berggren et al. (1985). 


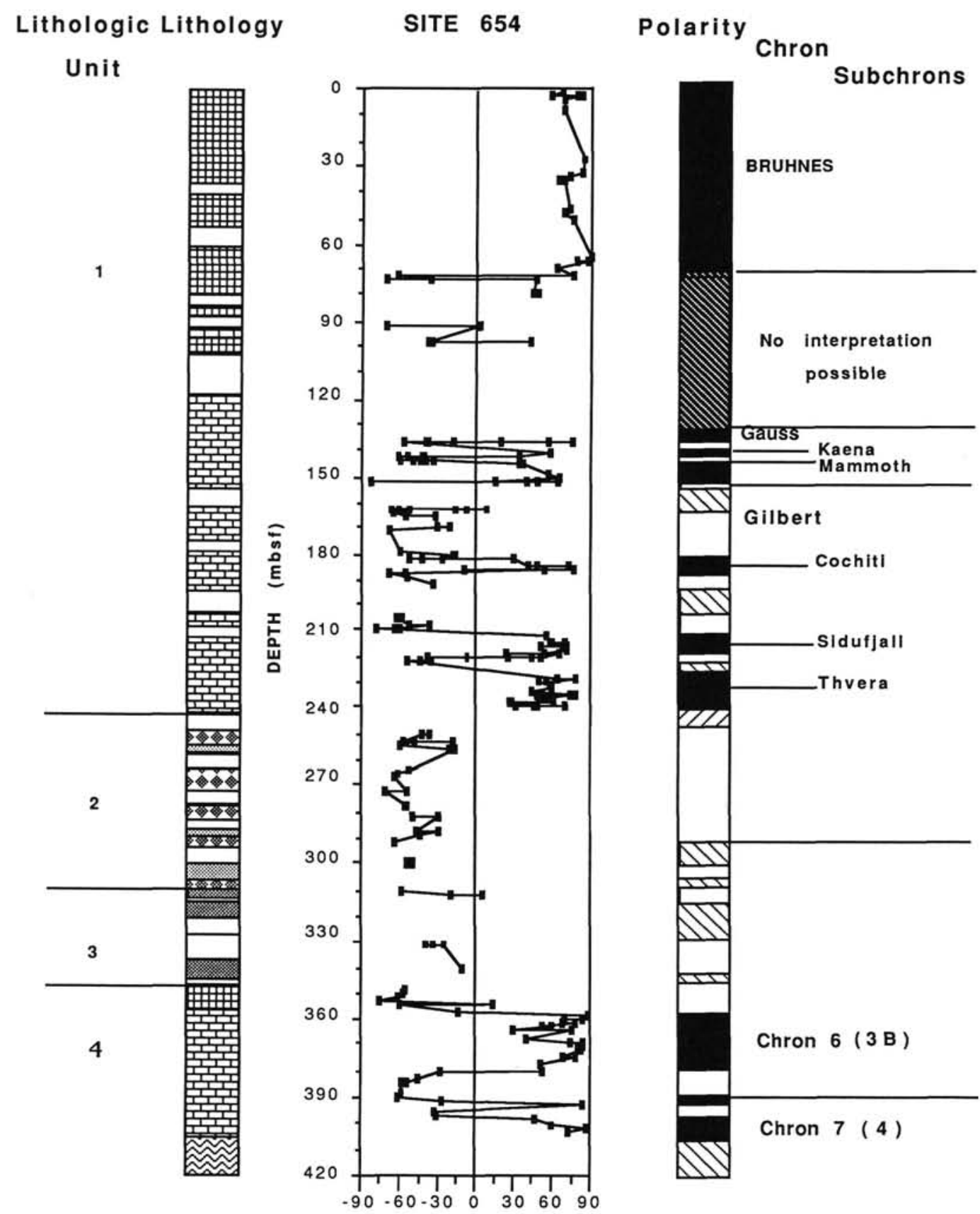

INCLINATION

Nannofossil ooze (marly) $\square$ No recovery 臣 Nannofossil ooze Gypsum, balatino type Mud \& clay Clays, silts, claystones \& siltstones $\approx$ Glauconitic sands dolomitic to calcareous

Figure 9. Lithologic log, inclination of the characteristic magnetization component, and polarity interpretation for Site 654. 


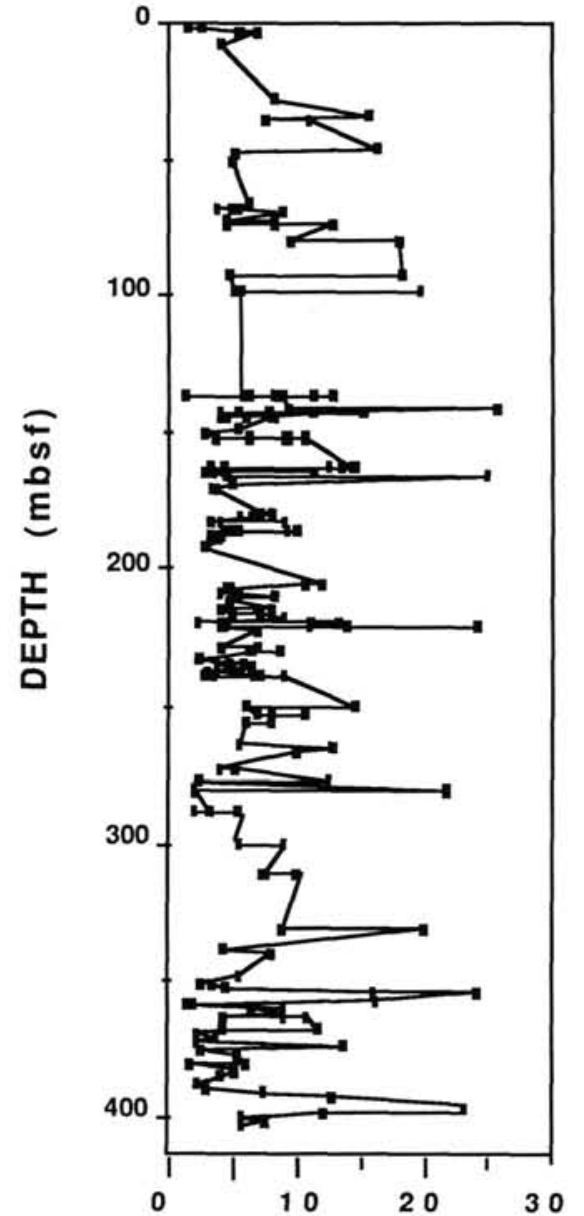

MAXIMUM ANGULAR DEVIATION (DEGREES)
Table 4. Locations of samples which bound reversals at Site 654. Table 1

\begin{tabular}{|c|c|c|c|c|}
\hline & Core & Section & $\begin{array}{c}\text { Interval } \\
(\mathrm{cm})\end{array}$ & $\begin{array}{l}\text { Depth } \\
\text { (mbsf) }\end{array}$ \\
\hline \multirow[t]{2}{*}{ Top of Kaena } & 15 & 6 & $137-139$ & 136.28 \\
\hline & 15 & 7 & 6-8 & 136.47 \\
\hline \multirow[t]{2}{*}{ Base of Kaena } & 15 & 7 & $32-34$ & 136.73 \\
\hline & 15 & 7 & $39-41$ & 136.80 \\
\hline \multirow[t]{2}{*}{ Top of Mammoth } & 16 & 4 & $41-43$ & 141.82 \\
\hline & 16 & 4 & $64-66$ & 142.05 \\
\hline \multirow[t]{2}{*}{ Base of Mammoth } & 16 & 5 & $3-5$ & 144.44 \\
\hline & 16 & 6 & $31-33$ & 144.72 \\
\hline \multirow[t]{2}{*}{ Top of Gilbert } & 17 & 4 & $82-84$ & 151.68 \\
\hline & 17 & 4 & $105-107$ & 151.96 \\
\hline \multirow[t]{2}{*}{ Top of Cochiti } & 20 & 5 & $102-104$ & 182.03 \\
\hline & 21 & 1 & $24-26$ & 184.85 \\
\hline \multirow[t]{2}{*}{ Base of Cochiti } & 21 & 2 & $45-47$ & 186.56 \\
\hline & 21 & 2 & $75-77$ & 186.86 \\
\hline \multirow[t]{2}{*}{ Top of Sidufjall } & 23 & 5 & $5-7$ & 209.86 \\
\hline & 23 & $\mathrm{CC}$ & $11-13$ & 211.42 \\
\hline \multirow[t]{2}{*}{ Base of Sidufjall } & 24 & 5 & $112-114$ & 220.53 \\
\hline & 24 & 5 & $137-139$ & 220.78 \\
\hline \multirow[t]{2}{*}{ Top of Thvera } & 24 & 6 & $74-76$ & 221.64 \\
\hline & 25 & 4 & $123-125$ & 228.84 \\
\hline \multirow[t]{2}{*}{ Base of Thvera } & 26 & 5 & $53-55$ & 239.24 \\
\hline & 27 & $\mathrm{CC}$ & $9-11$ & 250.46 \\
\hline \multirow[t]{2}{*}{ Top of Chron $6 n$ (3B) } & 40 & $\mathrm{CC}$ & $13-15$ & 357.34 \\
\hline & 41 & 1 & $50-52$ & 358.31 \\
\hline \multirow[t]{2}{*}{ Base of Chron $6 n(3 B)$} & 43 & 2 & $117-119$ & 379.78 \\
\hline & 43 & 3 & $84-86$ & 380.95 \\
\hline \multirow[t]{2}{*}{ Top of Chron $7 \mathrm{nl}(4)$} & 44 & 3 & $126-128$ & 391.07 \\
\hline & 44 & 4 & $140-142$ & 392.71 \\
\hline \multirow[t]{2}{*}{ Base of Chron $7 n 1$ (4) } & 44 & 4 & $140-142$ & 392.71 \\
\hline & 44 & 6 & $108-110$ & 395.39 \\
\hline \multirow[t]{2}{*}{ Top of Chron $7 n 2(4)$} & 45 & 1 & $40-42$ & 396.81 \\
\hline & 45 & 2 & $50-52$ & 398.41 \\
\hline
\end{tabular}

Figure 10. Maximum angular deviation (MAD) values as a function of depth for Site 654 . 


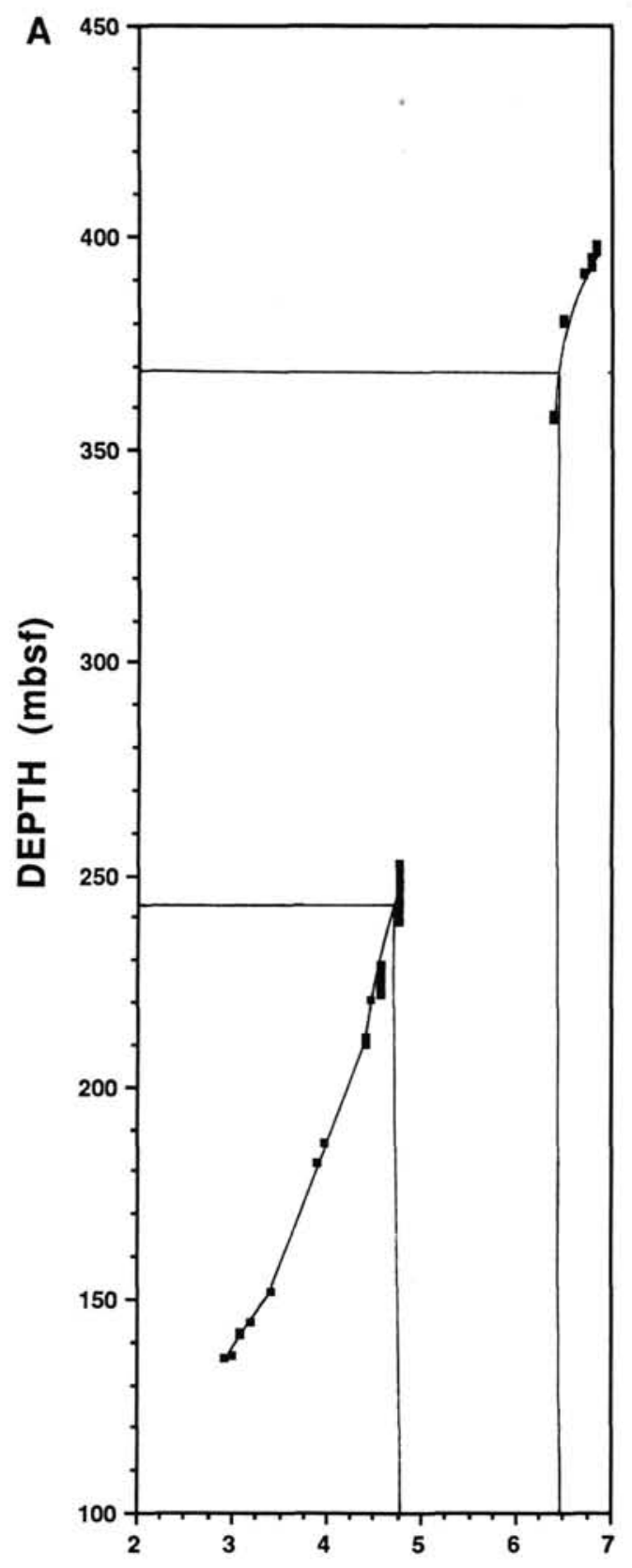

AGE (Ma)

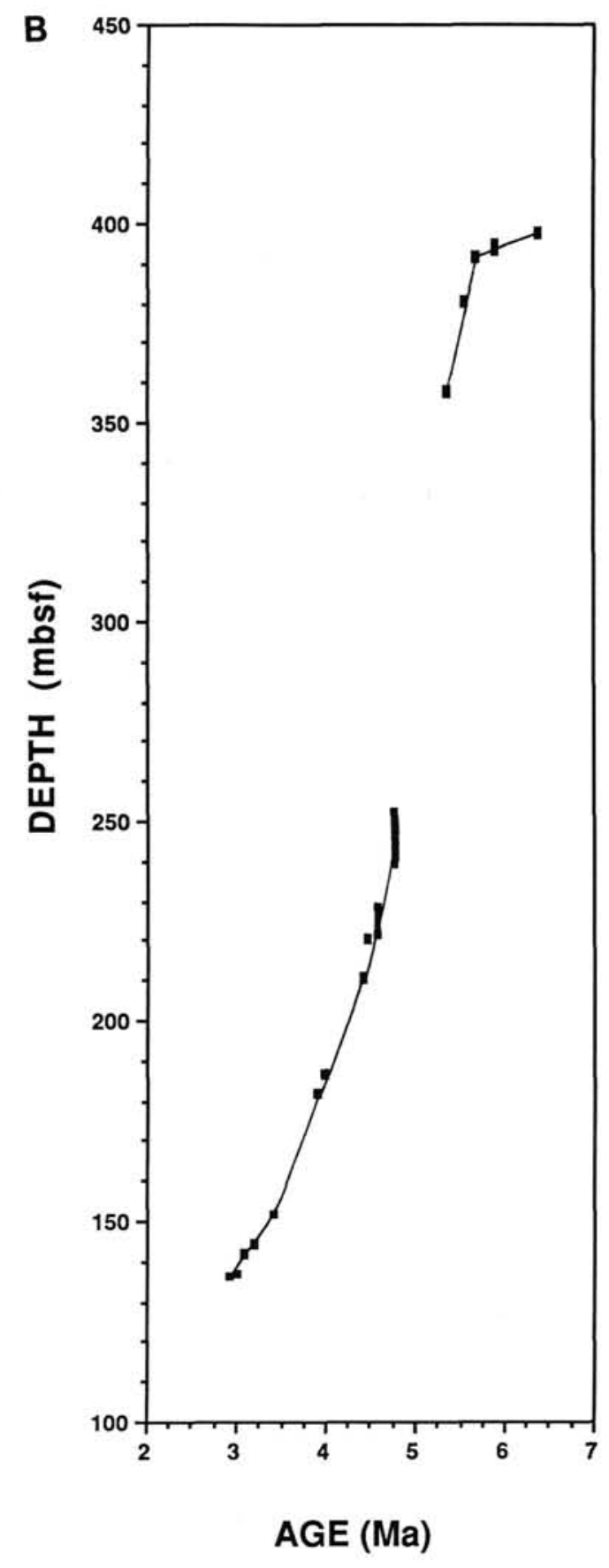

AGE (Ma)

Figure 11. Depth/age plots for Site 654 using the ages of reversal boundaries as given by Berggren et al. (1985) for the two alternative interpretations of the polarity sequence observed in Unit 4: (a) as Chrons 6 and 7 (Chrons 3B and 4 ) and (b) as Chrons 5 and 6 (Chrons $3 \mathrm{~A}$ and $3 \mathrm{~B}$ ). 